\title{
Current knowledge of the South East Asian large branchiopod Crustacea (Anostraca, Notostraca, Laevicaudata, Spinicaudata, Cyclestherida)
}

\author{
D. Christopher ROGERS, ${ }^{1,2^{*}}$ Wipavee THAIMUANGPHOL,${ }^{3}$ Nukul SAENGPHAN, ${ }^{4}$ La-orsri SANOAMUANG ${ }^{5,6}$
}

${ }^{1}$ Kansas Biological Survey and the Natural History Museum (Biodiversity Institute), Kansas University, 2101 Constant Avenue, Lawrence, 66047-3759 KS, USA; ${ }^{2}$ University of New England, 2351 Handel Street, Armidale, Australia; ${ }^{3}$ Faculty of Technology, Mahasarakham University, 44150 Maha Sarakham; ${ }^{4}$ Faculty of Fisheries, Suphanburi College of Agriculture and Technology, 72180 Suphanburi; ${ }^{5}$ Applied Taxonomic Research Center, Faculty of Science, Khon Kaen University, 40002 Khon Kaen; ${ }^{6}$ Faculty of Science, Mahasarakham University, 44150 Maha Sarakham, Thailand

*Corresponding author: Branchiopod@gmail.com

\begin{abstract}
The large branchiopod crustaceans (fairy shrimp, tadpole shrimp and clam shrimp) of South East (SE) Asia have only recently been examined with scientific vigor. Although more than 70 species have been reported for Asia and Indonesia, only six native taxa and one introduced species are known from SE Asia. The majority of records are from Thailand, with fewer than three records each from Laos, Myanmar, Malaysia, Cambodia, Vietnam, and Singapore. Eleven genera reported from adjacent regions may potentially occur in SE Asia. Spinicaudatan clam shrimp have been collected from Thailand and Cambodia, but have not been identified beyond genus. Four of the five native fairy shrimp species are endemic to SE Asia. The limited distributions of these few taxa suggest that this region has a distinct branchiopod fauna. In addition, we present new species and records of clam shrimp from Thailand. Future survey efforts will undoubtedly reveal additional taxa.
\end{abstract}

Key words: review, Lynceus, Cyzicus pilosus n. sp., Eulimnadia sp., surveys.

Received: January 2013. Accepted: April 2013.

\section{INTRODUCTION}

The extant members of the class Branchiopoda are the most primitive living crustaceans. Branchiopoda is comprised of four extant orders: the Anostraca (fairy shrimp), Notostraca (tadpole shrimp), Laevicaudata (smooth clam shrimp), and the Diplostraca (Rogers, 2009; Ahyong et al., 2011). The Diplostraca is further subdivided into three suborders: Spinicaudata (spiny clam shrimp), Cyclestherida (tropical clam shrimp), and the Cladocera (water fleas) (Brendonck et al., 2008; Rogers, 2009; Ahyong et $a l ., 2011)$. The Branchiopoda is artificially divided into two nontaxonomic groups: the large branchiopods and the water fleas for purposes of convenience, rather than on any systematic basis (Rogers, 2009). The Cladocera appear to be paedomorphic clam shrimp (Brabrand et al., 2002; De Waard et al., 2006).

Large branchiopod crustaceans occur in temporary and saline inland lentic habitats worldwide, including Antarctica (Brendonck et al., 2008; Rogers, 2009). These crustaceans are important indicators of seasonally astatic aquatic ecosystem health (Rogers, 2009) and some species are economically important (Baert et al., 1997; Bo et al., 2004; Sanoamuang et al., 2000a).

The large branchiopod crustaceans of South East (SE) Asia have only recently been examined with any scientific vigor and even then only from selected areas (Sanoamuang et al., 2000a, 2000b, 2002; Sanoamuang and Saengphan, 2006). Seventy two species have been reported from adjacent Eurasia and the Indian subcontinent, and only seven native taxa and one introduced species are known from SE Asia (Fig. 1). We review the known large branchiopod taxa from SE Asia (defined as Myanmar, Thailand, Laos, Vietnam, Cambodia, Malaysia, Singapore, Indonesia and the Philippines), discuss what taxa may be expected to occur in this region, present new species records, and describe a new species of clam shrimp from Thailand.

\section{METHODS}

The literature concerning the branchiopod fauna of Asia was reviewed. Materials examined are listed in the taxonomic accounts below, as appropriate. Specimens were examined using a Wild M-8 zoom stereoscope (Wild Heerbrugg, Heerbrugg, Switzerland). Identifications were made through comparison with material in D. Christopher Rogers' personal collections, and use of the appropriate taxonomic references. All drawings were made by hand. The taxonomic arrangement follows Ahyong et al. (2011), Rabet (2010), Rogers (2006, 2009), Brendonck et al. (2008), and Rogers et al. (2012). 


\section{RESULTS}

\section{Anostraca Sars, 1867}

\section{Artemiidae Grochowski, 1896}

The Artemiidae is a monogeneric family of halophilic species found worldwide, except for Antarctica (Brendonck et al., 2008; Rogers, 2009; Ahyong et al., 2011).

\section{Artemia Leach, 1819}

There are no records of naturally occurring populations of the halophilic genus Artemia in SE Asia, although the genus is well known from India (Bond, 1934; Belk and Esparza, 1995) and China (Sars, 1901; Wei, 1992; Belk and Brtek, 1995). The United Nations agency Food and Agriculture Organisation (FAO) in collaboration with the Artemia Reference Centre at Ghent University (Belgium) introduced Artemia francisana Kellogg, 1906 and a form from China to SE Asia to facilitate the aquaculture industry (Baert et al., 1997; Bo et al., 2004). Artemia francisana is native to the Americas, and has become an invasive species in Eurasia (Bo et al., 2004). The exact identity of the Chinese form is unknown (Hou et al., 2006). Artemia francisana was introduced to Thailand, the Philippines and Vietnam from the USA and Brasil. Artemia sp. from China was introduced to the Philippines and Vietnam.

\section{Streptocephalidae Daday, 1910}

The Streptocephalidae is monogeneric, with species distributed across Africa, Eurasia, Australia and North America (Daniels et al., 2004; Brendonck et al., 2008; Rogers, 2009; Ahyong et al., 2011).

\section{Streptocephalus Baird, 1852}

\section{South East Asian taxa}

Streptocephalus dichotomius Baird, 1860 is widely distributed across India and eastern Pakistan, with a single record in SE Asia from Rangoon, Myanmar (Bond, 1934; Belk and Brtek, 1995; Sanoamuang et al., 2000a, 2000b; Velu and Munuswamy, 2005).

Streptocephalus javaensis Brehm, 1955 is reported from a single locality in Purwakarta, Java (Vaas, 1952). It is treated here as a nomen dubium, as the original description is inadequate, and examination of Brehm's figures strongly suggest that the specimens are immature (Belk and Brtek, 1995). Vaas (1952) and Brehm (1955) both produced figures of this species; however, those figures do not match, may contain errors, and may represent two different taxa (Belk and Brtek, 1995). There are no other records of Streptocephalus from any part of Indonesia, so it is very likely that these specimens represent new taxa. However, until new and mature material is collected, these animals will remain inadequately known.

Streptocephalus sirindhornae Sanoamuang et al., 2000 (Fig. 1B) is widely distributed across Thailand, but rarely occurs in the southern peninsula (Sanoamuang et al., 2000a, 2000b). Our recent investigations show that it also inhabits southern Laos and Central Cambodia. In Thailand, this species is widely cultured commercially in aquacultural farms as live food for freshwater ornamental fish and prawns (Dararat et al., 2011; Sriputhorn and Sanoamuang, 2011). Frozen adults and dried eggs are sold in local markets, particularly in North East (NE) and Central Thailand, and are exported to other countries, such as Taiwan and Hong Kong. Adults are harvested from the wild, cooked and consumed by local people in NE Thailand (Sanoamuang and Dumont, 2000).

Streptocephalus (Parastreptocephalus) siamensis Sanoamuang and Saengphan, 2006 (Fig. 1C) is unique in that it is the only member of the subgenus Parastreptocephalus Brendonck, Hammer and Thiéry, 1992 reported from Eurasia. The other members of this subgenus occur in Africa and Australia (Brendonck et al., 1992; Herbert and Timms, 2000). The subgenus is distinguished from the nominate form by having tetrahedral eggs. Streptocephalus siamensis is only known from two localities in central Thailand and may be extinct in the wild, although it is actively cultured in laboratories.

\section{Other potential taxa}

Streptocephalus simplex Gurney, 1906 occurs across from the Arabian peninsula, northern India, and East into Bangladesh (Bond, 1934; Belk and Brtek, 1995). It is possible that this species may occur in Myanmar. Streptocephalus echinus Bond, 1934, S. longimanus Bond, 1934, and S. spinifer Gurney, 1906 also occur in India, but are limited to the southern regions.

An as yet undetermined Streptocephalus species belonging to the subgenus Parastreptocephalus is reported from Siaolanyu island of the southeastern coast of Taiwan (Li et al., 2010; Li, personal communication).

\section{Branchipodidae Simon, 1886}

There are no records of any branchipodids from SE Asia (Brendonck et al., 2008; Rogers, 2009). The only genus occurring in eastern Asia is Branchipodopsis Sars, 1898, represented by Branchipodopsis affinis Sars, 1901 (Belk and Brtek, 1995). This species is widespread through India, eastern China, Mongolia, and adjacent parts of Russia (Belk and Brtek, 1995), and thus may occur in the northern or northwestern portions of SE Asia.

\section{Thamnocephalidae Packard, 1883}

The Thamnocephalidae is composed of six genera, 
with three reported from Asia (Rogers, 2006, 2009; Brendonck et al., 2008; Ahyong et al., 2011). Only one genus is reported from SE Asia and adjacent areas.

\section{Branchinella (Branchinellites) (Daday, 1910a)}

\section{South East Asian taxa}

One thamnocephalid was recently described from Thailand: Branchinella thailandensis Sanoamuang et al., 2002 (Fig. 1A). This species is sporadically distributed across Central and NE Thailand (Sanoamuang et al., 2000a, 2002), and contains a high concentration of carotenoids, particularly astaxanthin, compared to other crustaceans. It is therefore used for colour enhancement in ornamental fish cultures (Dararat et al., 2012).

\section{Other potential taxa}

Branchinella (Branchinellites) kugenumaensis (Ishikawa, 1895) is widespread in Taiwan, Korea, Japan, and western China as far South as Yunnan (Brendonck and Belk, 1997; Huang et al., 2010; Rogers et al., In press). It is likely that this species may occur in northern Myanmar, Thailand, Laos and Vietnam.

Branchinella (Branchinellites) maduraiensis (Raj, 1951 ) is widespread in southern India (Raj, 1951, 1961).

\section{Branchinectidae Daday, 1910}

The family Branchinectidae has one Eurasian genus (Brendonck et al., 2008; Rogers, 2009), with two species in Asia. There are no records from SE Asia for this temperate genus. Branchinecta orientalis Sars, 1901 is reported from the Himalayas in Nepal (Manca and Mura, 1997). Similar habitat for this species may be present at higher altitudes in Kachin State, Myanmar, and Chang Rai province, Thailand.

\section{Chirocephalidae Daday, 1910}

Nine genera of chirocephalids are recognised worldwide, with six occurring in Asia (Brendonck et al., 2008; Rogers, 2009; Ahyong et al., 2011). Only one genus occurs in SE Asia and adjacent areas.

\section{Chirocephalus Prevost, 1803}

\section{South East Asian taxa}

The genus Chirocephalus is the second largest genus of Anostracans, second only to Streptocephalus (Rogers, 2009), and is generally distributed across temperate Eurasia. One species, Chirocephalus hardingi Brtek, 1965, is known from SE Asia. This species is known from a single collection from the southern coast of the island of Bali, Indonesia. It is the only species in the genus known from a tropical climate.

\section{Other potential taxa}

The fact that one species in this temperate habitat genus is found in Bali, suggests that more species may occur between Indonesia and China or India. Chirocephalus priscus (Daday, 1910) occurs in the northern mountains of India and C. nankinensis (Shen, 1933), C. sinensis Thiele, 1907, and C. wangi Hsu, 1933 all occur in western China. It is probable that any of these or more species may be found in SE Asia in the future.

\section{Notostraca Sars, 1867}

\section{Triopsidae Keilhack, 1909}

There are no records of notostracans from SE Asia (Brendonck et al., 2008; Rogers, 2009). Triops cancriformis (Schaeffer, 1756) is reported from various parts of India (Kemp, 1911; Walton and Kemp, 1911; Bond, 1934; Chacko, 1950; Tiwari, 1954, 1955; Mathur and Sidhu, 1957; Shanbhag and Inamdar, 1968), and T. granarius (Lucas, 1864) is known from India, Mongolia, China, and Japan (Sars, 1901; Longhurst, 1955; Xue et al., 2010; Grygier et al., 2002). It is very likely that one or both species will be found in mainland SE Asia in the future.

In addition, the North American Triops longicaudatus (LeConte, 1846) has been introduced to Japan (Grygier et $a l ., 2002)$ through the rice industry and may eventually be introduced to the mainland.

\section{Laevicaudata Linder, 1945}

\section{Lynceidae Baird, 1845}

\section{South East Asian taxa}

We present here the first records of Lynceus from SE Asia. Laevicaudatans have not previously been reported from SE Asia (Martin and Belk, 1988; Brendonck et al., 2008; Rogers, 2009). We have collections of two species of Lynceus. One of our species may be conspecific with L. alleppeyensis Balaraman and Nayar, 2004, and is still being analysed. The other represents a particularly distinct new species that will be described elsewhere.

\section{Other potential taxa}

Lynceus biformis (Ishikawa, 1895) is reported from adjacent China and Taiwan. This widespread species was originally described from Japan (Ishikawa, 1895a).

Some five species of Lynceus are reported from India: L. indicus Daday, 1927, L. caecus (Joseph, 1882), L. denticulatus Gurney, 1930 (including L. serratus Royan and Alfred, 1971), L. vastishi Battish, 1981, and L. alleppeyensis (Martin and Belk, 1988). However, these species all need to be re-evaluated according to modern standards, as the validity of some are doubtful. 

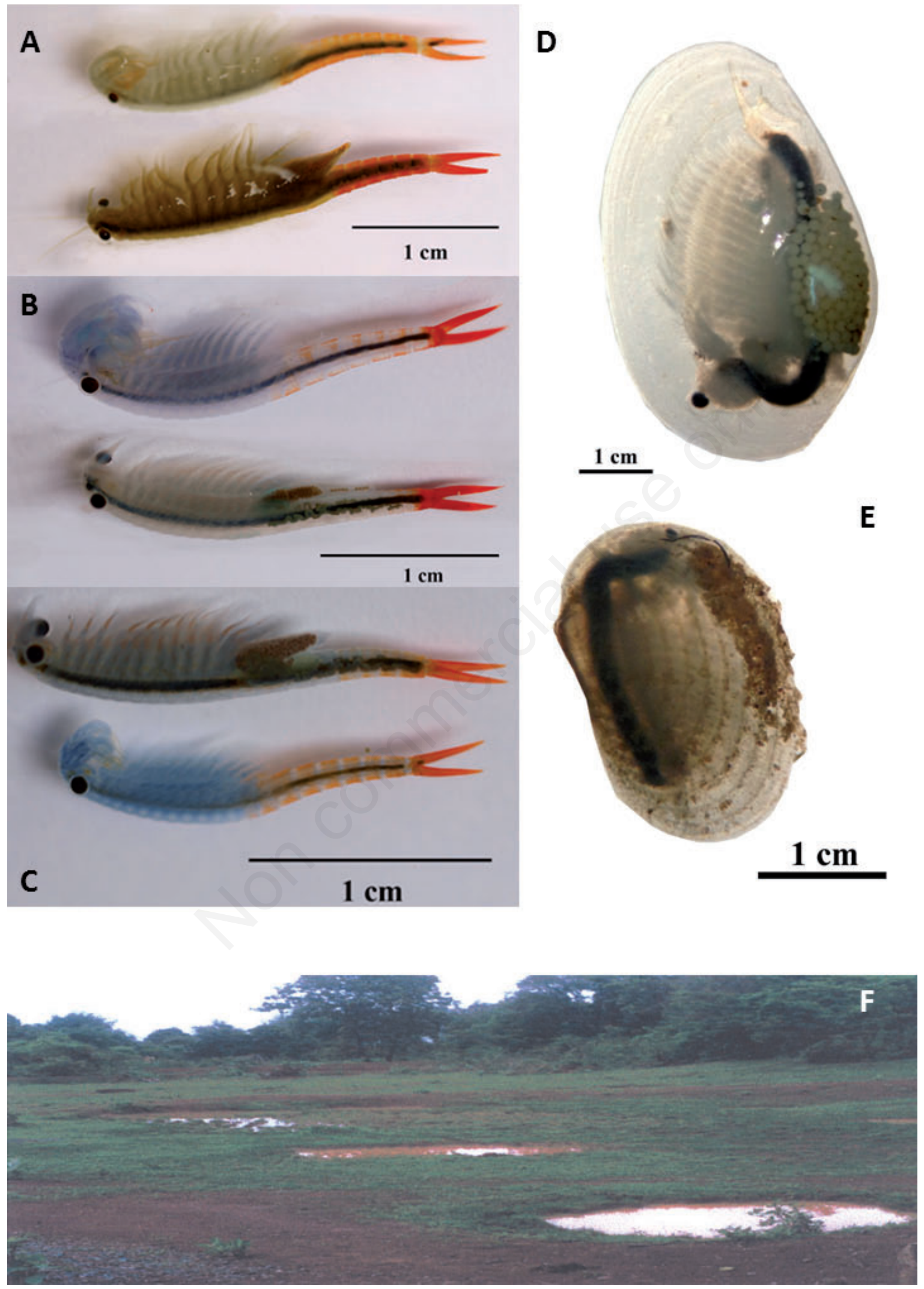

Fig. 1. Examples of South East Asian large branchiopod crustaceans (A-E) and habitats (F). A) Branchinella thailandensis; B) Streptocephalus sirindhornae; C) S. siamensis; D) Eulimnadia sp.; E) Cyzicus pilosus n. sp.; F) buffalo wallows. 


\section{Diplostraca Gerstaecker, 1866}

\section{Suborder Spinicaudata Linder, 1945}

\section{Cyzicidae Stebbing, 1910}

We present the first records of the clam shrimp family Cyzicidae from SE Asia (Brendonck et al., 2008; Rogers, 2009). Durga Prasad and Simhachalam $(2004,2009)$ mention $E$. orientalis from the Indomalayan region, but do not provide any SE Asian records.

Eight species are reported from adjacent India: Eocyzicus bouveri Daday, 1913, E. deterranus Bond, 1934, E. dhilloni Battish, 1981, E. hutchinsoni Bond, 1934, E. orientalis Daday, 1913, E. palpalis Simhachalam and Timms, 2012, E. pellucidus Tiwari, 1962, and E. plumosus Royan and Sumitra, 1973 (Simhachalam and Timms, 2012). These species of Eocyzicus needs must be re-examined according to modern standards, and we expect that many are synonyms.

Eocyzicus bouvieri and E. orientalis are also found in southern China as well (Hu, 1988). Other Chinese taxa include: E. mongolianus Uéno, 1927, E. liayangensis Hu, 1985, Cyzicus gifuensis (Ishikawa, 1895), and C. davidi (Simon, 1886) (Hu, 1988). Cyzicus nepalensis Uéno, 1967 , is known from Nepal.

We expect that the genus Eocyzicus will eventually be found in SE Asia. We present the first record of Cyzicus from SE Asia.

\section{Cyzicus pilosus n. sp.}

Types: holotype, male. Data: Thailand, Maha Sarakham province, Kosum Phisai district. Temporary pond at Ban Hae Tai, N 16² $5^{\prime} 56.5^{\prime}$ ', E 10308'27.65”, $10 \mathrm{~m}$ asl; 1 August 2012, L. Sanoamuang. Paratypes; two males, two females, same data.

Type locality: the type locality is a temporary pond that is used to culture freshwater fish larvae for commercial purposes. The hydroperiod is about 3 months. Other invertebrates which co-occur in the pond are Streptocephalus sirindhornae, Moina sp., Micronecta sp., Esanthelphusa dugasti (Rathbun, 1902) and Filopaludina sumatrensis (Dunker, 1852). Surrounding land uses are rice paddy fields and fish farms.

Additional material examined: Thailand: Maha Sarakham province, Kosum Phisai district. Ban Hae Tai, fish larva pond; $\mathrm{N} 16^{\circ} 16^{\prime}, \mathrm{E} 103^{\circ} 08^{\prime}$; W. Ban Hae Tai, fish larva pond; N $16^{\circ} 15^{\prime} 56.50^{\prime \prime}, \mathrm{E} 103^{\circ} 08^{\prime} 27.65^{\prime},, 10 \mathrm{~m}$ asl; 1 August 2012, D.C. Rogers, K. Van Damme, L. Sanoamuang. Thaimuangphol. Suphanburi province: Donchedi district; roadside ditch flooded by rainwater, N 1444', E 9950'; 4 July 2011; N. Saengphan. Donchedi district; roadside ditch flooded by rainwater, N 1440', E 99 53'; 12 May 2012; N. Saengphan. Donchedi district; flooded rice paddy, N 14²2', E 9952’; 12 May 2010; N. Saeng- phan. Muang district; cultured from soil collected from a rice paddy N 14³0', E 9953'; 5, 10, 15 April 2012; N. Saengphan.

Etymology: the specific epithet pilosus comes from the Latin word pilos meaning hair or hairy. The gender is masculine.

Description: average carapace length of preserved material: $4.0 \mathrm{~mm}$. Average carapace valve height: $2.6 \mathrm{~mm}$ $(\mathrm{n}=25)$ (Figs. 1E, 2A-C, and 3A).

Male: head with ocular tubercle prominent anteriorly. Head broader than ocular tubercle. Contiguous compound eyes large, subcircular, 0.7 times the width of the ocular tubercle. Occipital crest conical, length 1.2 times basal width, directed posteriorly, with a deep, narrow cleft separating it from the dorsoposterior portion of the head. Naupliar ocellus elongate, lying within rostrum. Rostrum pronounced, triangular, dorsomedially depressed, broadly rounded to truncated, length subequal to the distance from the compound eye to the occipital crest. Rostral apex subacute and slightly upturned. Ventral surface of rostrum even with ventral surface of head.

First antennae well below and posterior to rostrum, pedunculate, and 0.8 times as long as second antennae. First antennae antennomeres lobed or bilobed anteriorly, lacking obvious setae. Second antennae 2 to 3 times as long as head. Second antennal peduncle one third the length of head, cylindrical, and bearing anterior, obliquely transverse rows of plumose setae. Second antennal anterior flagellum (exopod) with five to eight flagellomeres, posterior flagellum (endopod) with eight to eleven flagellomeres. Flagellomeres each anteriorly with a longitudinal row of three to five long spines and a single distally directed spine, and posteriorly with a longitudinal row of elongate plumose setae.

Carapace broadly oval, with numerous growth lines. Umbone prominent. Hinge line straight, with one to five short, sharp carinae (at growth line apices) at posterior end. Apical most carina most prominent. Growth lines margined with setae. Distal (youngest) growth lines and carapace margin densely pilose, with some setae worn off on older growth lines. Younger growth lines with stout setae, as long as growth line intervals, separated by their basal width. Carapace lateral and posterior margins with a fringe of long fine setae. Intervals between growth lines with stout, radial, raised carinae. Interspaces between carinae with a polygonal micromesh pattern. Adductor muscle scar broad, oblong, about twice as long as wide.

Fourteen to nineteen pairs of thoracopods, with first and second pairs modified as claspers.

Thoracopod I clasper [terminology follows McLaughlin (1980)] endite V subcylindrical, strongly arcuate, and flattening slightly in distal fourth, with gripping surface bearing fine, stout, triangular denticles. Endite V with an anteroproximal hemispherical protrusion. Endite VI subcylindrical, slightly longer than endite V, lacking denti- 


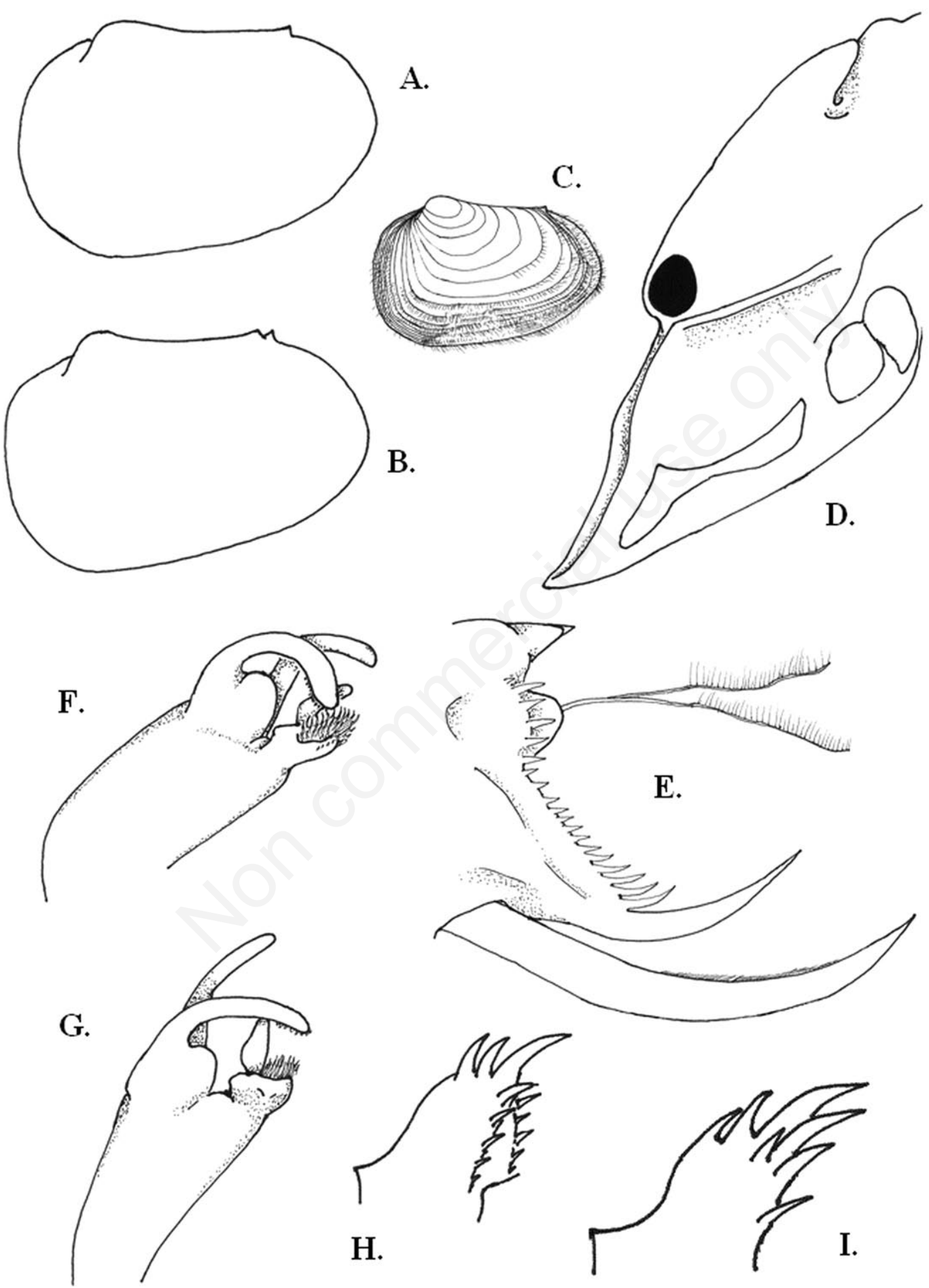

Fig. 2. Cyzicus pilosus n. sp. A) Example outline of male carapace, left valve; B) example outline of female carapace, left valve; C) carapace, left valve; D) head, male, left lateral view; E) telson and cercopods, left lateral view; F) left thoracopod I, male, lateral view; G) left thoracopod I, male, medial view; H) example of dorsal thoracic protuberance, left lateral view; I) example dorsal thoracic protuberance, left lateral view. 
cles. Endite IV broad and flat with a medial palp. Palp digitiform. Endite IV apex broad, densely covered in elongate, recurved, apically acute spines. Endite III lobiform.

Post cephalic body segments VI, VII, or VIII through IX with a single dorsomedial spiniform projection. Remaining posterior body segments each with a single dorsomedial, lobiform projection, directed posteriorly, and bearing a longitudinal row of two or three elongate, posteriorly curved spines, and bearing three to four posteriolateral spines.

Telson with a dorsal mound bearing a pair of large conical spines, as broad as high. Telson posteriolateral ridges with 18 to 20 pairs of spines, distal pairs becoming elongated and arcuate, with the distal most pair 1.5 times longer than the proximal pair. Caudal filaments originating on a hemispherical projection between the ridges at or about the third pair of spines. Telson posteriolateral ridges each terminating in an elongated spiniform projection, 3 to 4 times as long as the nearest spines. Cercopods projecting posteriorly from the ventral surface of the telson. Cerci are longer than the telson, with four proximomedial spines with setaform apices and a dorsal fringe of fine setae on the middle third.

Female: head as in male. Sixteen to eighteen pairs of thoracopods, with ninth and tenth pairs bearing dorsally elongated flabellae for carrying the eggs. Thoracic segments and telson as in male.

Egg: spherical, smooth and unornamented; typical for the genus, with no diagnostic characteristics. Diameter approximately $100 \mu \mathrm{m}$.

Differential diagnosis: Cyzicus pilosus n. sp. is easily separated from all other species of Cyzicus except $C$. gifuensis by the dense pilosity of the carapace distolateral surfaces and margins and the stout setae on the older

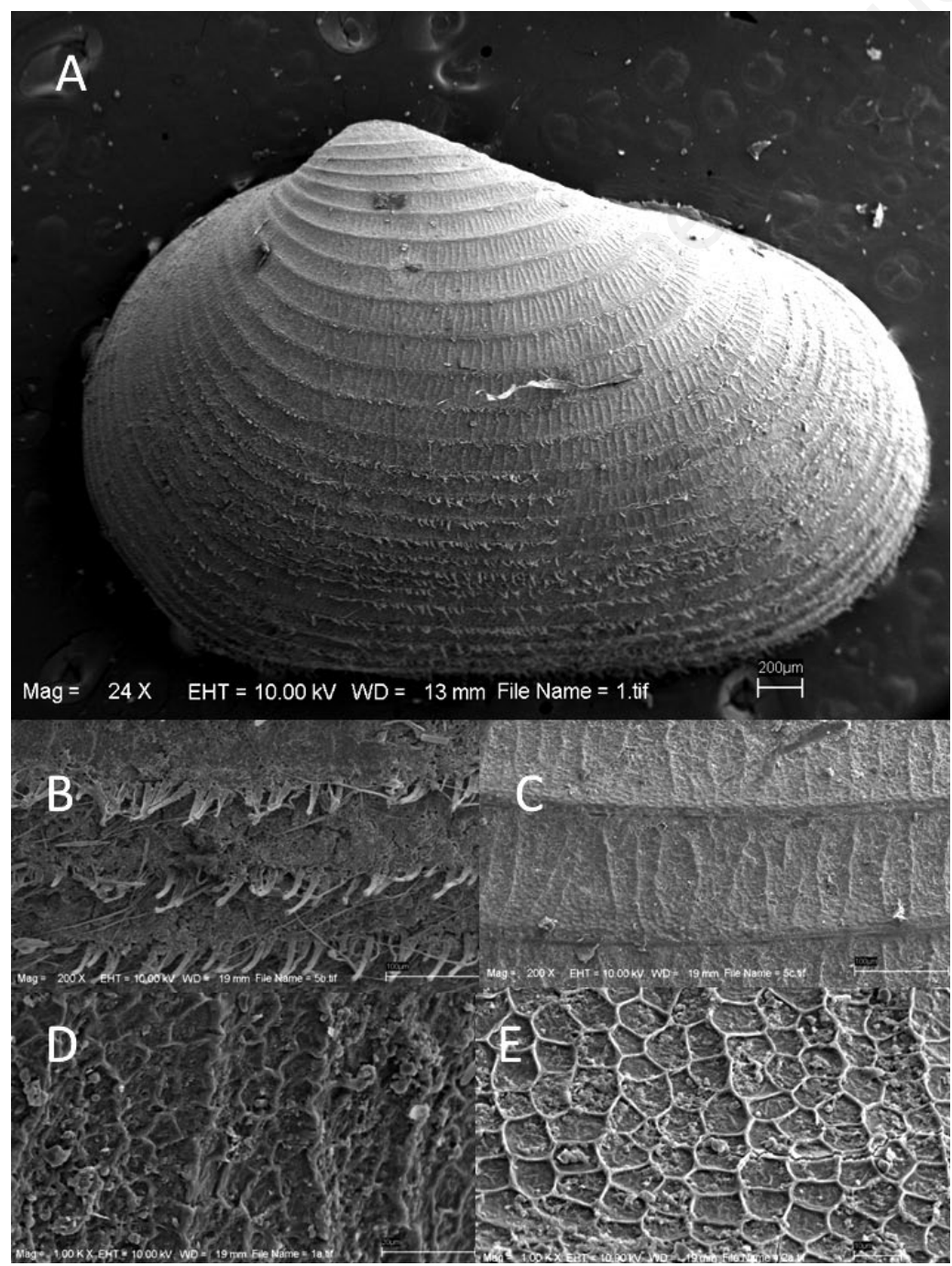

Fig. 3. Cyzicus pilosus n. sp. A) Carapace, left valve; B) detail of carapace growth line, depicting setal fringe; C) detail of carapace, depicting interspace carinae; D) detail of carinae, depicting polygonal micromesh surface; E) detail of polygonal micromesh. 
growth lines. The denser pilosity of the carapace margins is apt to become coated in mud, algae or debris, and the setae of the older growth lines, particularly on the valve disc may be worn off.

Cyzicus pilosus n. sp. is separated from C. gifuensis by the shape of the male rostrum, which is quadrangular in C. gifuensis and triangular in C. pilosus n. sp. Furthermore, the cercopods of $C$. gifuensis are dorsally margined in the proximal portion with serrated spines. Such spines are lacking in C. pilosus n. sp.

Distribution and habitat: Cyzicus pilosus $\mathrm{n}$. $\mathrm{sp}$. is so far only known from Thailand. It has been collected from roadside ditches, aquaculture ponds, and rice paddies (Fig. 4).

\section{Leptestheriidae Daday, 1923}

There are no records of leptestheriid clam shrimp from SE Asia at this time (Garcia and Pereira, 2003, Brendonck et al., 2008; Rogers, 2009). A mostly complete world checklist of the family is presented by Garcia and Pereira (2003). Eleven species in two genera have been reported from surrounding regions of India and China; however, we expect that many of these species will be determined invalid after careful scrutiny. For example, Leptestheria longispinosa Nayar, 1965 [L. longispina in error in Garcia and Pereira (2003)] is apparently based upon juvenile Leptestheria material.

India currently has five species: Leptestheria $d u$ monti Subhash Babu and Bijoy Nandan, 2010, L. jaisalmerensis Tiwari, 1962, L. nobilis Sars, 1900, L. sarsi Daday, 1923, and Leptestheriella simhadrii Simhachalam and Timms, 2012.

China currently has three species: L. kawachiensis Uéno, 1927, L. dahalacensis (Rüppel, 1837), and Eoleptestheria ticinensis (Balsamo-Crivelli, 1859). Leptestheria kawachiensis ranges across southern China, whereas the other species are recorded from northeastern and northwestern China (Hu, 1988).

Therefore, it is reasonable to assume that representatives of this family may be expected in SE Asia.

\section{Limnadiidae Baird, 1849}

Two limnadiid genera occur in Asia (Ishikawa, 1895b; Rogers et al., 2012). The genus Limnadia has one species in the northern hemisphere [L. lenticularis (Linnaeus, 1761)] that is reported from India and Japan (Rogers et al., 2012). The other genus (Eulimnadia) is widespread in Asia and in need of revision (Rabet, 2010; Rogers et al., 2012).

\section{Eulimnadia Packard, 1874}

\section{South East Asian taxa}

There are two incomplete records of Eulimnadia from
SE Asia. The first is a report of an unidentified collection of Eulimnadia sp. from northeastern Thailand (Martin et al., 2003). The second is a collection of Eulimnadia from Cambodia with similar egg morphology as the Neotropical E. magdalensis Roessler, 1990 (Rabet, 2010). These collections need closer examination.

To this, we add our own collections of Eulimnadia sp. from Thailand. Most of our collections lack eggs, thus making a definitive identification impossible. However, one specimen has eggs that do not appear fully shelled (Fig. 1D). The eggs have the superficial appearance of the North American E. diversa Mattox, 1937 or E. agassizii Packard, 1874.

\section{Other taxa}

Eight species are reported from India and three from adjacent China; however, as previously stated for other clam shrimp families, these taxa need to be examined using modern standards. Rogers et al. (2012) demonstrated the unreliability of characters typically used to define limnadiid clam shrimp, and Rabet (2000) argues from experiment and the literature that only egg morphology are reliable for delimiting Eulimnadia species.

From India are reported: $E$. chaperi (Simon, 1886), E. compressa (Baird, 1860), E. gibba Sars, 1900, E. gunturensis Radhakrishna and Durga Prasad, 1976, E. indocylindrova Durga Prasad and Simhachalam, 2012, E. margaretae Bond, 1934, E. michaeli Nayar and Nair, 1968, E. ovata Nayar, 1965 (including E. ovata inversa Batish, 1981), and E. similis Sars, 1900.

There are four species reported from China: $E$. aethiopica Daday, 1913, E. taoluensis Hu, 1986, E. kobai Uéno, 1940, and an undescribed species reported in Shen and Huang (2008).

\section{Suborder Cyclestherida Sars, 1899}

\section{Cyclestheriidae Sars, 1899}

Cyclestheria hislopi (Baird, 1859) is generally described as a monotypic, circumtropically distributed clam shrimp (Olesen et al., 1996), although doubts concerning the number of species remain (Olesen et al., 1996; Martin and Boyce, 2004; Rogers, 2009; Schwentner et al., 2013). A recent molecular analysis suggests that several cryptic species are present (Schwentner et al., 2013). The distribution of this species in SE Asia was reviewed by Martin et al. (2003) and Martin and Boyce (2004), reporting records from Cambodia, Celebes, Java, Malaysia, Singapore, Sulawesi, Sumatra, and Thailand. Typically collections come from dense aquatic vegetation in permanent ponds and wetlands (Martin et al., 2003). 
A

B

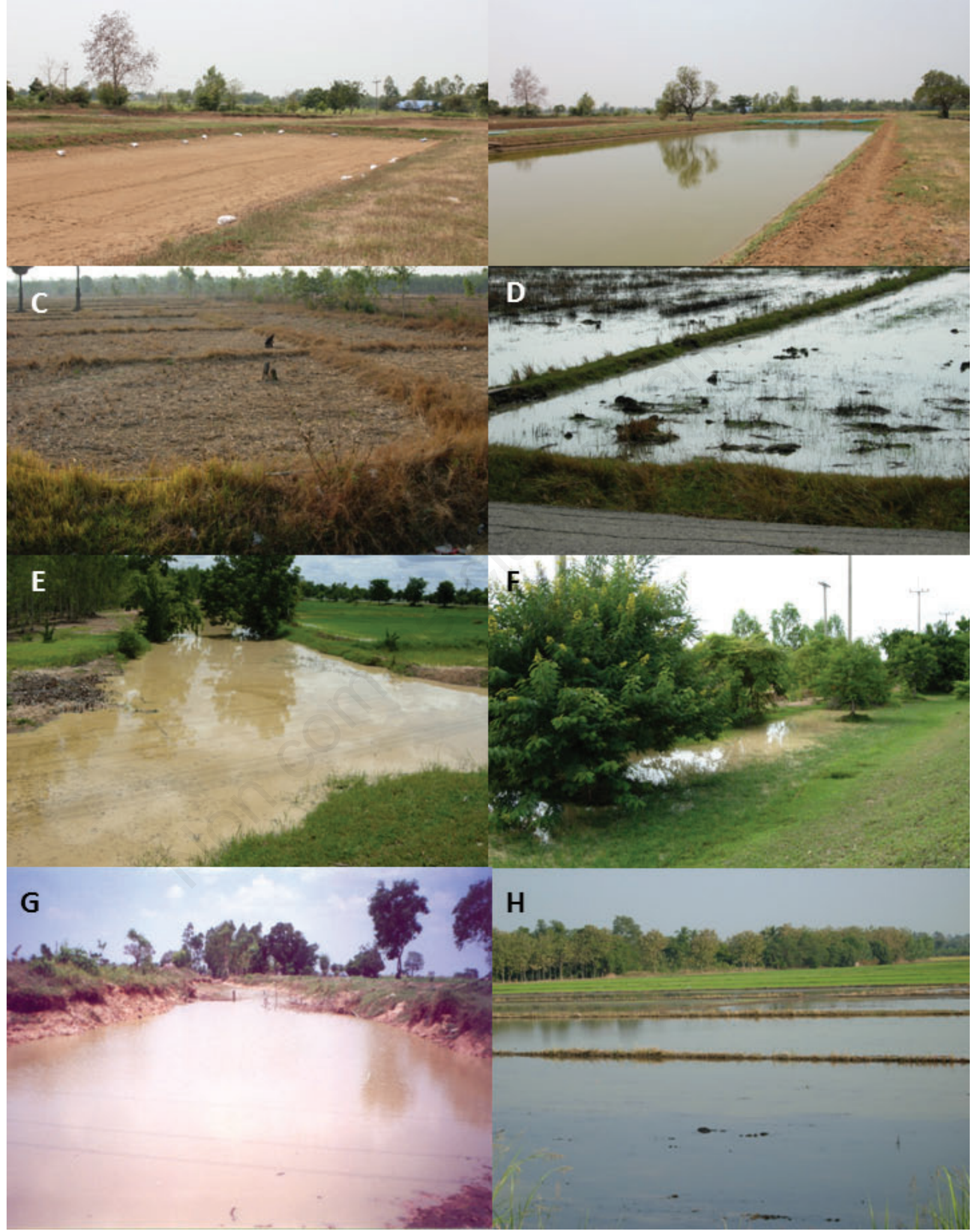

Fig. 4. Cyzicus pilosus n. sp. type locality A) dry, and B) inundated. Examples of large branchiopod habitats in Thailand: rice paddy, C) dry, and D) inundated; E, F) roadside ditches; G) temporary wetland; H) rice paddy, inundated. 


\section{DISCUSSION}

There are eight described and three (possibly four) undescribed large branchiopod species reported from SE Asia. When compared to the 68 described species from adjacent India, Nepal and China, it is obvious that the large branchiopod diversity of SE Asia has been understudied. It is ironic that this paper was read at the Freshwater Invertebrates of SE Asia workshop, and the following day we found Cyzicus pilosus n. sp. during a field trip. Obviously, there are more taxa in SE Asia to find, and we have made some limited predictions in the text above and in Tab. 1.

Recent revisions of some clam shrimp groups have been beneficial to our understanding (Martin and Belk, 1988; Rogers et al., 2012); however, more work needs to be done, particularly in Asia. The diversity of spinicaudatan clams shrimp in India and China appears artificially inflated with roughly one fourth of the world described species from these two nations alone. In the most recent taxa lists of Indian and Chinese clam shrimp (Hu, 1988; Durga Prasad and Simhachalam, 2009), 24 species are reported, with seven in genera that are no longer recognised taxonomically (Caenestheria, Caenestheriella), and many species that are regarded as junior synonyms of other taxa (e.g. Leptestheria hendersoni (Sars, 1900), L. gigas Karande and Inamdar, 1960, and L. maduraiensis Nayar and Nair, 1968) (Simhachalam and Timms, 2012).

Large branchiopod crustaceans primarily occur in seasonally astatic wetlands (Rogers, 2009). In SE Asia, this would include temporary wetlands (Fig. 4G), water buffalo wallows (Fig. 1F), salt ponds, rice paddies (Fig. 4C, $4 \mathrm{D}$, and $4 \mathrm{H}$ ), roadside ditches (Fig. 4E and $4 \mathrm{~F}$ ), and storm water retention basins (Fig. 3) (Sanoamuang et al., 2000b, 2002; Rogers, 2009).

Little of SE Asia has been explored for large branchiopod crustaceans. There are no records from the montane grassland and shrubland regions of Malaysia, Myanmar, Indonesia, the Philippines, and Thailand. Furthermore, much of the seasonally dry forest regions of Cambodia, Laos, the Philippines, and Vietnam have not been surveyed for seasonally astatic wetland fauna.

Potential large branchiopod habitat can be surveyed one of two methods: wet season sampling or the Sars' method (Van Damme and Dumont, 2010). Wet season sampling consists of using dip nets to sample standing water in habitats with the potential to support large branchiopods. The animals are swept from the water column and preserved in ethyl alcohol for examination and identification.

Sars' method (Van Damme and Dumont, 2010) is used when habitats are not readily accessible when they are wet (due to barriers of mud, snow, wildlife or timing) but may be accessible when they are dry. Soil samples, that may include branchiopod eggs, are collected from the dry substrate and removed to the laboratory for hydration and rearing. This method has been employed to discover new branchiopods from many different regions.

\section{CONCLUSIONS}

It is obvious that much work needs to be done as regards large branchiopods. The species reported from Indonesia need to be verified, and much potential habitat remains to be explored. We remain confident that new taxa and new records remain to be discovered in SE Asia.

Tab. 1. Large branchiopod diversity of South East Asia as compared to adjacent regions, global and South East Asia diversity, and the predicted expected numbers of species for South East Asia (genera/species).

\begin{tabular}{|c|c|c|c|c|}
\hline & Global & Regional & SEA & Expected \\
\hline \multicolumn{5}{|l|}{ Anostraca } \\
\hline Artemiidae & $1 / 7$ & $1 / 3$ & $1 / 2 ?$ & $0 / 0$ \\
\hline Thamnocephalidae & $8 / 72$ & $1 / 3$ & $1 / 1$ & $1 / 2$ \\
\hline Streptocephalidae & $1 / 63$ & $1 / 5$ & $1 / 5$ & $1 / 6$ \\
\hline Branchinectidae & $2 / 51$ & & $0 / 0$ & $1 / 1$ \\
\hline Branchipodidae & $6 / 34$ & $1 / 1$ & $0 / 0$ & $1 / 1$ \\
\hline Chirocephalidae & $9 / 83$ & $1 / 4$ & $1 / 1$ & $1 / 2$ \\
\hline \multicolumn{5}{|l|}{ Notostraca } \\
\hline Triopsidae & $2 / 15$ & $1 / 2$ & $0 / 0$ & $1 / 1$ \\
\hline \multicolumn{5}{|l|}{ Laevicaudata } \\
\hline Lynceidae & $3 / 36$ & $1 / 6$ & $0 / 0$ & $1 / 4$ \\
\hline \multicolumn{5}{|l|}{ Diplostraca } \\
\hline Limnadiidae & $8 / \sim 55$ & $2 / 11$ & $1 / 2 ?$ & $2 / 7$ \\
\hline Cyzicidae & 4/ 90 & $1 / 13$ & $1 / 1$ & $1 / 5$ \\
\hline Leptestheriidae & $3 / \sim 37$ & $2 / 8$ & $0 / 0$ & $2 / 3$ \\
\hline Cyclestheriidae & $1 / 1$ & $1 / 1$ & $1 / 1$ & $1 / 1$ \\
\hline
\end{tabular}

SEA, South East Asia. 


\section{ACKNOWLEDGMENTS}

This work was supported by the Higher Education Research Promotion and National Research University Project of Thailand, Office of the Higher Education Commission, through the Food and Functional Food Research Cluster of Khon Kaen University. We are also grateful to Brian Timms and the anonymous reviewer who improved the manuscript with their suggestions. We would especially like to thank Kay Van Damme for his great encouragement.

\section{REFERENCES}

Ahyong ST, Lowry JK, Alonso M, Bamber RN, Boxshall GA, Castro P, Gerken S, Karaman GS, Goy JW, Jones DS, Meland K, Rogers DC, Svavarsson J, 2011. Subphylum Crustacea Brünnich, 1772. Zootaxa 3148:165-191. Available from: http://www.mapress.com/zootaxa/2011/f/zt03148p 191.pdf

Baert P, Anh NTN, Quynh VD, Hoa NV, 1997. Increasing cyst yields in Artemia culture ponds in Vietnam: the multi-cycle system. Aquac. Res. 28:809-814.

Belk D, Brtek J, 1995. Checklist of the Anostraca. Hydrobiologia 298:315-353.

Belk D, Esparza CE, 1995. Anostraca of the Indian subcontinent. Hydrobiologia 298:287-293.

Bo Z, Shichun S, Lin M, 2004. The occurrence of an exotic bisexual Artemia species, Artemia franciscana, in two coastal salterns of Shandong Provence, China. J. Ocean Univ. China 3:171-174.

Bond RM, 1934. Report on phyllopod Crustacea (Anostraca, Notostraca and Conchostraca) including a revision of the Anostraca of the Indian Empire. Mem. Connect Acad. Arts Sci. 10:29-62.

Brabrand A, Richter S, Hiesel R, Sholtz G, 2002. Phylogenetic relationships within the Phyllopoda (Crustacea, Branchiopoda) based on mitochondrial and nuclear markers. Mol. Phylogenet. Evol. 25:229-244.

Brehm V, 1955. [Ein neuer Streptocephalus aus Indonesien (Streptocephalus javanensis n. sp.). Sitzungsberichte der Kaiserlichen Akademie der Wissenschaften]. [Article in German]. Sitzungsberichten Akad. Wiss. Math.-naturw. Klasse Wien 164:249-254.

Brendonck L, Belk D, 1997. Branchinella maduraiensis Raj (Crustacea, Branchiopoda, Anostraca) shown by new evidence to be a valid species. Hydrobiologia 359:93-99.

Brendonck L, Hamer M, Thiéry A, 1992. Occurrence of tetrahedral eggs in the Streptocephalidae Daday (Branchiopoda: Anostraca) with descriptions of a new subgenus, Parastreptocephalus, and a new species, Streptocephalus (Parastreptocephalus) zuluensis Brendonck and Hamer, 1992. J. Crustacean Biol. 12:282-297.

Brendonck L, Rogers DC, Olesen J, Weeks S, Hoeh R, 2008. Global diversity of Large branchiopods (Crustacea: Branchiopoda) in fresh water. Hydrobiologia 595:167-176.

Chacko PI, 1950. Occurrence of the fairy shrimp (sic) Apus, in a temple water tank in Tirunelveli District, Madras. J. Bomb. Nat. Hist. Soc. 49:571.

Daniels SR, Hamer M, Rogers DC, 2004. Molecular evidence suggests an ancient radiation for the fairy shrimp genus
Streptocephalus (Branchiopoda: Anostraca). Biol. J. Linn. Soc. 82:313-327.

Dararat W, Lomthaisong K, Sanoamuang L, 2012. Biochemical composition of three species of fairy shrimp (Branchiopoda: Anostraca) from Thailand. J. Crustacean Biol. 32:81-87.

Dararat W, Starkweather PL, Sanoamuang L, 2011. Life history of three fairy shrimps (Branchiopoda: Anostraca) from Thailand. J. Crustacean Biol. 31:623-629.

De Waard JR, Sacherova V, Cristescu MEA, Remigio EA, Crease TJ, Hebert PDN, 2006. Probing the relationships of the branchiopod crustaceans. Mol. Phylogenet. Evol. 39:491-502.

Durga Prasad MK, Simhachalam G, 2004. Eulimnadia indocylindrova sp. nov. (Branchiopoda: Spinicaudata) from South India with a review of the genus Eulimnadia in Indomalayan region, p. 74-81. In: Kathmandu University (ed.), Proc. Int. Conf. on Great Himalayas: Climate, Health, Ecology Management and Conservation. KU/AEHMS/HIRI Publ.

Durga Prasad MK, Simhachalam G, 2009. Distribution of Indian clam shrimps (Branchiopoda: Crustacea). Curr. Sci. India 96:71-73.

Garcia JV, Pereira G, 2003. A review of the clam shrimp family Leptestheriidae (Crustacea: Branchiopoda: Spinicaudata) from Venezuela, with descriptions of two new species. Zootaxa 208:1-12.

Grygier MJ, Kusuoka Y, Ida M, 2002. Lake Biwa field reporters. Distributional survey of large branchiopods of rice paddies in Shiga Prefecture, Japan: a Lake Biwa museum project based on lay amateur participation. Hydrobiologia 486:133-146.

Herbert D, Timms BV, 2000. A new species of Streptocephalus (Parastreptocephalus) (Crustacea: Anostraca; Streptocephalidae) from north Queensland, Australia. Mem. Queensl. Mus. 45:385-390.

Hou L, Bi X, Zou X, He C, Yang L, Qu R, Liu Z, 2006. Molecular systematics of bisexual Artemia populations. Aquac. Res. 37:671-680.

$\mathrm{Hu}$ W, 1988. Studies of clam shrimps (Crustacea: Conchostraca) II. Sixteen species of Conchostraca in China. J. Ocean Univ. Qingdao 18:66-86.

Huang S-L, Wang C-C, Huang W-P, Chou L-S, 2010. Indeterminate growth of the fairy shrimp, Branchinella (Branchinellites) kugenumaensis (Branchiopoda; Anostraca) in an unpredictable ephemeral pool. J. Crustacean Biol. 30:366-372.

Ishikawa C, 1895a. Phyllopod Crustacea of Japan. Dobutsugaku Zasshi (Zool. Mag. Tokyo) 7:8-12.

Ishikawa C, 1895b. Phyllopod Crustacea of Japan. Dobutsugaku Zasshi (Zool. Mag. Tokyo) 7:13-20.

Kemp S, 1911. Notes on Major Walton's specimens and other from Kashmir with a list of previous records from eastern Asia. Rec. Indian Museum 6:353-357.

Li J-J, Ko F-C, Li J-J, 2010. Crustaceans on Siaolanyu Isle of Taiwan. Platax 7:1-11.

Longhurst AR. 1955. A review of the Notostraca. Bull. Brit. Mus. (Nat. Hist. Zool.) 3:1-57.

Manca M, Mura G, 1997. On Branchinecta orientalis Sars (Anostraca) in the Himalayas. Hydrobiologia 356:111-116.

Martin JW, Belk D, 1988. Review of the clam shrimp family Lynceidae Stebbing, 1902 (Branchiopoda: Conchostraca), in the Americas. J. Crustacean Biol. 8:451-482.

Martin JW, Boyce SL, 2004. Crustacea: non-cladoceran Bran- 
chiopoda, p. 284-297. In: C.M. Yule and Y.H. Sen (eds.), Freshwater invertebrates of the Malaysian region. Academy of Sciences Malaysia ed.

Martin JW, Boyce SL, Grygier MJ, 2003. New records of $C y$ clestheria hislopi (Baird, 1859) (Crustacea: Branchiopoda: Diplostraca: Cyclestherida) in Southeast Asia. Raffles B. Zool. 51:215-218.

Mathur SN, Sidhu N, 1957. Occurrence of Apus (Crustacea: Notostraca) in Pilani, Rajasthan. J. Bomb. Nat. Hist. Soc. 54:961-962.

McLaughlin P, 1980. Comparative morphology of recent Crustacea. W.H. Freeman \& co. ed., San Francisco: 177 pp.

Olesen J, Martin JW, Roessler EW, 1996. External morphology of the male of Cyclestheria hislopi (Baird, 1859) (Crustacea: Branchiopoda: Spinicaudata) with a comparison of the male claspers among the Conchostraca and Cladocera and its bearing on phylogeny of the 'bivalved' Branchiopoda. Zool. Scr. 25:291-316.

Rabet N, 2010. Revision of the egg morphology of Eulimnadia (Crustacea, Branchiopoda, Spinicaudata). Zoosystema 32:373-391.

Raj PJS, 1951. The first record of the genus Branchinella Sayce in India and a new variety of Branchinella kugenumaensis (Ishikawa), var. madurai. Curr. Sci. India 20:334.

Raj PJS, 1961. Morphology and distribution of Branchinella kugenumaensis (Ishikawa), var. madurai, Raj (Branchiopoda: Crustacea). Ohio J. Sci. 61:257-262.

Rogers DC, 2006. A genus level revision of the Thamnocephalidae (Crustacea: Branchiopoda: Anostraca). Zootaxa 1260:1-25.

Rogers DC, 2009. Branchiopoda (Anostraca, Notostraca, Laevicaudata, Spinicaudata, Cyclestherida), p. 242-249. In: G.F. Likens (ed.), Encyclopedia of inland waters. 2. Academic Press.

Rogers DC, Rabet N, Weeks SC, 2012. Revision of the extant genera of Limnadiidae (Branchiopoda: Spinicaudata). J. Crustacean Biol. 32:827-842.

Rogers DC, Shu S, Yang J, (2013). The identity of Branchinella yunnanensis Shen, 1949, with a brief review of the subgenus Branchinellites (Branchiopoda: Anostraca: Thamnocephalidae). J. Crustacean Biol. (in press).

Sanoamuang L, Dumont HJ, 2000. Fairy shrimp: a delicacy in northeast Thailand. Anost. News 8:3.

Sanoamuang L, Murugan G, Weekers PHH, Dumont HJ, 2000a. Streptocephalus sirindornae, new species of freshwater fairy shrimp (Anostraca) from Thailand. J. Crustacean Biol. 20:559-565.

Sanoamuang L, Sanoamuang N, Saengphan N, Chusing R, Athibai S, Lekchan S, 2000b. Species diversity and distribution of fairy shrimps in Thailand. Khon Kaen University ed., Khon Kaen: 19 pp.
Sanoamuang L, Saengphan N, 2006. A new species of Streptocephalus fairy shrimp (Crustacea, Anostraca) with tetrahedral cysts from Central Thailand. Int. Rev. Hydrobiol. 91:250-256.

Sanoamuang L, Saengphan N, Murugan G, 2002. First record of the family Thamnocephalidae (Crustacea: Anostraca) from Southeast Asia and description of a new species of Branchinella. Hydrobiologia 486:63-69.

Sars GO, 1901. On the Crustacean fauna of Central Asia. I. Amphipoda and Phyllopoda. Ann. Mus. Zool. Acad. Sci. St. Petersbourg 4:130-164.

Schwentner M, Clavier S, Fritsch M, Olesen J, Padhye S, Timms BV, Richter S, 2013. Cyclestheria hislopi (Crustacea: Branchiopoda): a group of morphologically cryptic species with origins in the Cretaceous. Mol. Phylogenet. Evol. 66:800-810.

Shanbhag SV, Inamdar NB, 1968. On the occurrence of Triops mavliensis (Tiwari), Notostraca (Crustacea) in the Okhamandal Region of Saurashtra (India). J. Bomb. Nat. Hist. Soc. 65:408-417.

Shen YB, Huang DY, 2008. Extant clam shrimp egg morphology: taxonomy and comparison with other fossil branchiopod eggs. J. Crustacean Biol. 28:352-360.

Simhachalam G, Timms BV, 2012. Two new species of Spinicaudata (Crustacea: Branchiopoda) in south India with a key to Leptestheriella and Eocyzicus. Zootaxa 3161:20-36.

Sriputhorn K, Sanoamuang L, 2011. Fairy shrimp (Streptocephalus sirindhornae) as live feed improve growth and carotenoid contents of giant freshwater prawn Macrobrachium rosenbergii. Int. J. Zool. Res. 7:138-146.

Tiwari KK, 1954. Sex ratio and variability of apodous segments in Apus (Phyllopoda: Crustacea). J. Bomb. Nat. Hist. Soc. 52:641-644.

Tiwari KK, 1955. Reproduction in the Notostraca. J. Bomb. Nat. Hist. Soc. 53:491-492.

Vaas KF, 1952. [Merkwaardige lagere kreeften]. [Article in Dutch]. De Tropische Natuur 32:131-133.

Van Damme K, Dumont HJ, 2010. Cladocera of the Lençóis Maranhenes (NE - Brazil): faunal composition and a reappraisal of Sars' method. Braz. J. Biol. 70(Suppl.3):755-779.

Velu CS, Munuswamy N, 2005. Updated diagnoses for the Indian species of Streptocephalus (Crustacea: Branchiopoda: Anostraca). Zootaxa 1049:33-48.

Walton SJ, Kemp S, 1911. Notes on the occurrence of Apus in eastern India. Rec. Indian Museum 6:351-352.

Wei D-Y, 1992. The discovery and its geological significance of fossil faecal pellets of brine shrimp in mirabilite deposit. Chinese Sci. Bull. 37:1017-1021.

Xue J-Z, Fang W, Wu H-X, Yuan L, Wang B-Q, 2010. The morphology of Triops sinensis and appendage characteristics on different segments. Sichuan J. Zool. 29:209-214. 